\title{
Differential inhibition of human cytomegalovirus (HCMV) by toll-like receptor ligands mediated by interferon-beta in human foreskin fibroblasts and cervical tissue

\author{
Sailesh C Harwani, Nell S Lurain, M Reza Zariffard and Gregory T Spear*
}

Address: Department of Immunology/Microbiology, Rush University, Chicago, USA

Email: Sailesh C Harwani - Sailesh_harwani@hotmail.com; Nell S Lurain - nlurain@rush.edu; M

Reza Zariffard - mohammadreza_zariffard@rush.edu; Gregory T Spear* - gspear@rush.edu

* Corresponding author

Published: 5 December 2007

Virology Journal 2007, 4:133 doi:10.1186/1743-422X-4-133

This article is available from: http://www.virologyj.com/content/4/I/I33

(c) 2007 Harwani et al; licensee BioMed Central Ltd.

This is an Open Access article distributed under the terms of the Creative Commons Attribution License (http://creativecommons.org/licenses/by/2.0), which permits unrestricted use, distribution, and reproduction in any medium, provided the original work is properly cited.
Received: 5 October 2007

Accepted: 5 December 2007

\begin{abstract}
Human cytomegalovirus (HCMV) can be acquired sexually and is shed from the genital tract. Crosssectional studies in women show that changes in genital tract microbial flora affect HCMV infection and/or shedding. Since genital microbial flora may affect HCMV infection or replication by stimulating cells through Toll-like receptors (TLR), we assessed the effects of defined TLR-ligands on HCMV replication in foreskin fibroblasts and ectocervical tissue. Poly I:C (a TLR3-ligand) and lipopolysaccharide (LPS, a TLR4-ligand) inhibited HCMV and induced secretion of IL-8 and Interferon-beta (IFN $\beta$ ) in both foreskin fibroblasts and ectocervical tissue. The anti-HCMV effect was reversed by antibody to IFN $\beta$. CPG (TLR9 ligand) and lipoteichoic acid (LTA, TLR2 ligand) also inhibited HCMV infection in ectocervical tissue and this anti-HCMV effect was also reversed by anti-IFN $\beta$ antibody. In contrast, LTA and CPG did not inhibit HCMV infection in foreskin fibroblasts. This study shows that TLR ligands induce an HCMV-antiviral effect that is mediated by IFN $\beta$ suggesting that changes in genital tract flora may affect HCMV infection or shedding by stimulating TLR. This study also contrasts the utility of two models that can be used for assessing the interaction of microbial flora with HCMV in the genital tract. Clear differences in the response to different TLR ligands suggests the explant model more closely reflects in vivo responses to genital infections.
\end{abstract}

\section{Background}

The seroprevalence of human cytomegalovirus (HCMV) in the United States general population is approximately $60 \%$ and is even higher in certain socioeconomic groups [1]. HCMV causes severe disease when immunity is suppressed such as in organ transplant recipients or during the later stages of HIV-1 infection [2]. HCMV infection can be transmitted by bodily fluids of infected individuals, including saliva, blood, semen and cervical/vaginal secretions [3]. Infection of infants can occur from expo- sure to genital fluids during birth and this route of infection can lead to mild to severe neurological sequelae.

Several studies suggest that alterations of genital tract flora in women can affect either initial infection by HCMV or virus replication/shedding. For example, HCMV DNA was detected more frequently in vaginal washings from women with bacterial vaginosis (BV) than in women with normal genital tract flora [4]. BV is an alteration of the female genital tract flora consisting of an increase in both 
gram negative and gram positive bacteria [5]. Increased HCMV shedding is also associated with concurrent Chlamydia trachomatis or Neisseria gonorrhoeae infection [6]. Further, infection with Trichomonas vaginalis, N. gonorrhoeae, and BV are associated with increased intrauterine transmission of HCMV [7]. The cause of the relationship between HCMV, BV and other sexually transmitted infections (STI) is not currently understood although inflammatory changes caused by STI could influence HCMV infection. Inflammation in genital tract infections is in many cases caused by the activation of genital tract cells through Toll-like receptor (TLR)-ligands derived from the pathogens; N. gonorrhoeae, T. vaginalis and BV flora all have been found to express products that activate TLR [810].

In contrast to the studies that show enhancement of HCMV infection or shedding by genital tract infections, other studies show that stimulation through TLR can induce an antiviral state in cells or in animals [11]. For example, replication of HSV-2 in vaginally-infected mice was prevented by intra-vaginal application of purified TLR ligands [12,13]. Similarly, intravenous injection of ligands for TLR3, $-4,-5,-7$, and -9 inhibit virus replication in Hepatitis B-transgenic mice [14]. The anti-viral effect in these studies was mediated by induction of type I interferons via TLR stimulation $[14,15]$.

In this study, we determined the effect of defined TLR ligands on HCMV replication as a model to better understand how changes in genital tract flora may enhance or inhibit HCMV replication in vivo. Since there are currently no animal models that are susceptible to HCMV, and only certain human cells are susceptible to HCMV infection, the effect of TLR ligands on replication of HCMV was assessed in foreskin fibroblasts (HFF), a previously described in vitro model of HCMV infection $[16,17]$. The TLR ligand effects were also studied in ectocervical tissue explants since HCMV was recently shown to replicate in this tissue and this may represent a model that more accurately represents in vivo infection by the virus [18].

\section{Materials and methods Cells, tissues, \& reagents}

Human Foreskin Fibroblasts (HFF) were maintained in culture medium comprised of Minimum Essential Medium (Gibco, Carlsbad, CA) with $10 \mathrm{mM}$ HEPES, 2 $\mathrm{mM}$ L-glutamine, $50 \mu \mathrm{g} / \mathrm{ml}$ gentamycin, $2.5 \mu \mathrm{g} / \mathrm{ml}$ amphotericin B, and 10\% fetal bovine serum (FBS; BioWhittaker, Walkersville, MD). Cervical tissue was obtained at Northwestern University Medical Center from women undergoing planned hysterectomy for benign disease who had no history of cervical dysplasia. Patient consent was obtained by the treating physicians.
An HCMV clinical strain was engineered to express the Renilla green fluorescent protein under the control of the HCMV major immediate early promoter [19]. The recombinant strain, HCMVPT30-gfp, produces extracellular virus and has similar growth kinetics as the parental strain [18].

Purified lipoteichoic acid (LTA) from S. aureus and lipopolysaccharide (LPS) from E. coli O11:B4 were obtained from Sigma Aldrich (St. Louis, MO). Poly I:C (PIC) was obtained from Amersham (Piscataway, NJ). CpG 2395, a type C oligodeoxynucleotide, was generously contributed by Coley Pharmaceuticals (Wellesley, MA).

\section{Treatment and infection of HFF}

HFF were grown to $95 \%$ confluency in 24-well culture plates and treated with either medium alone or TLR ligands. After $24 \mathrm{~h}$, medium was removed and assayed for cytokines. Cells were washed and CMVPT30-gfp was added $(\mathrm{moi}=0.05)$. Cells were cultured for four hours, the virus inoculum was removed, and cells were cultured an additional 10 days. Monolayers were inspected by epifluorescent microscopy and the number of GFP-positive cells or clusters of cells (foci) was determined.

\section{Cytokine ELISA}

IL-8, IL-10, IL-12, and TNF- $\alpha$ were quantitated in cell culture fluids using CytoSet ELISA kits from Biosource (Carlsbad, California). IFN- $\alpha$ was tested using the IFN- $\alpha$ Module Set from Bender Medsystems (Burlingame, CA). IFN- $\beta$ was assayed by coating 96 -well flat bottom plates (NUNC, Rochester, NY) with $3 \mu \mathrm{g} / \mathrm{ml}$ monoclonal mouse anti-human IFN- $\beta$ (Chemicon, Temecula, CA). Wells were blocked with $1 \%$ bovine serum albumin in phosphate buffered saline for $2 \mathrm{~h}$ at $25^{\circ} \mathrm{C}$, washed three times and samples added and incubated for $1 \mathrm{~h}$ at $25^{\circ} \mathrm{C}$. After washing, $3.5 \mu \mathrm{g} / \mathrm{ml}$ polyclonal rabbit anti-human IFN $\beta$ (Chemicon) was incubated in wells for one hour at $25^{\circ} \mathrm{C}$ followed by a 1/10,000 dilution of mouse anti-rabbit coupled to horseradish peroxidase (Chemicon) for $1 \mathrm{~h}$ at $25^{\circ} \mathrm{C}$.

\section{IFN- $\beta$ neutralization}

HFF were grown to $95 \%$ confluency in 24-well culture plates and treated with either medium alone, Poly I:C (10 $\mu \mathrm{g} / \mathrm{ml})$ or LPS $(10 \mu \mathrm{g} / \mathrm{ml})$ for $24 \mathrm{~h}$. Cells were washed twice with medium and incubated at $37^{\circ} \mathrm{C}$ in $1 \mathrm{ml}$ of fresh medium for $1 \mathrm{~h}$ to maximize removal of residual stimuli. Medium was replaced with $1 \mathrm{ml}$ of complete medium and cells were cultured for an additional 24 hour period. Conditioned supernatants were collected and incubated with either complete medium, rabbit polyclonal anti-IFN- $\beta$ neutralizing antiserum (Chemicon) (final concentration of $2 \times 10^{4}$ neutralization units $/ \mathrm{ml}$ ), or normal rabbit serum (NRS) (diluted 1:500 to give the same concentra- 
tion of rabbit antibody) for $1 \mathrm{~h}$ at $37^{\circ} \mathrm{C}$. The treated supernatants were then transferred to fresh 24-well culture plates containing confluent naïve HFF, and cultured for 24 hours. Conditioned medium was then removed and HFF challenged with CMVPT30-gfp. Fluorescent cells were counted by microscopy on day 10 after infection.

\section{Treatment and infection of ectocervical tissue}

Cervical tissues were washed extensively, cut into pieces of approximately $3 \mathrm{~mm}^{3}$, and cultured in 48 well plates similar to a previously described method [20] except that three ectocervical tissue pieces were cultured in each well of 48 well plates [18]. Tissues were cultured in $0.5 \mathrm{ml}$ medium containing Dulbeco's Modified Essential Medium, 24\% Ham's nutrient mixture, $5 \mu \mathrm{g} / \mathrm{ml}$ insulin, $50 \mu \mathrm{g} / \mathrm{ml}$ gentamicin, $100 \mathrm{U}$ penicillin $/ 100 \mu \mathrm{g} / \mathrm{ml}$ streptomycin, $20 \mathrm{mM}$ HEPES, $2 \mathrm{mM}$ L-glutamine, $1 \mathrm{~mm}$ sodium pyruvate, and 10\% FBS. TLR ligands were added to wells and cultured for 24 hours. Culture supernatants were removed and assayed for cytokines. Tissue pieces were washed and infected with HCMV ( $10^{5}$ pfu per well) for four $\mathrm{h}$ at $37^{\circ} \mathrm{C}$. Tissue pieces were washed again and then cultured for 10 days.

\section{PCR quantitation of HCMV infection}

Ectocervical explant tissue samples that were infected with HCMV were harvested and weighed. DNA was extracted using the Qiamp DNA Mini kit (Qiagen, Valencia, CA) and assayed by real-time PCR using primers for the DNA Polymerase gene of HCMV [18]. The forward primer used was 5'-CTCGTGCGTGTGCTACGAGA-3' and the reverse primer used was 5'-GCCGATCGTRAAGAGATGAAGAC3'. A FAM-AGTGCAGCCCCGRCCATCGTTC-TAMRA probe was used for detection of amplified product and a standard curve was generated using known copy numbers of genomic DNA from HCMV strain AD169 (Advanced Biotechnologies Inc., Columbia, MD). Results were expressed as HCMV copies/mg tissue.

\section{Expression of TLR by HFF and ectocervical explant tissue} HFF, tissue, HEK293 were lysed and RNA extracted using the RNeasy Mini Kit (Qiagen, Stanford Valencia, CA). cDNA was made from $1 \mu \mathrm{g}$ RNA from each cell type using the RT-PCR Kit from Clontech (Palo Alto, CA). The TLR primers were designed using Clone Manager Primer Software (4 Sci-ed, Durham, NC) based on gene sequences obtained from GeneBank (National Center of Biotechnology Information, NIH, Bethesda, MD). The primers were; TLR2 (F 5-CTCCAATCAGGCTTCTCT-3, R 5-TCAGTATCTCGCAGTTCC-3); TLR3 (F 5-GCATTCGGAATCTGTCTCTG-3，R 5-ATTCCTGGCCTGTGAGTTCT-3); TLR4 (F 5-GATGCCAGGATGATGTCT-3， R 5-CCGCAAGTCTGTGCAATA-3); TLR9 (F 5-TACCTTGCCTGCCTTCCTAC3, R 5-CAACACCAGGCCTTCAAGAC-3); and GAPDH (F 5-GAAGGTGAAGGTCGGAGTC-3， R 5-GAAGATGGT-
GATGGGATTTC-3). Amplification was carried out using a GeneAMP Thermocycler (Perkin Elmer, Norwalk, CT) with a thermocycler profile as follows; Stage $1,94^{\circ} \mathrm{C}(5$ min); stage 2,35 cycles of $94^{\circ} \mathrm{C}$ ( $\left.45 \mathrm{sec}\right), 62^{\circ} \mathrm{C}$ (45 sec) and $72^{\circ} \mathrm{C}(1 \mathrm{~min})$ and Stage $3,72^{\circ} \mathrm{C}(10 \mathrm{~min})$.

\section{Results \\ TLR3 and TLR4 ligands but not TLR2 or TLR9 ligands induce IL-8 secretion in foreskin fibroblasts}

Initial experiments were performed to determine if ligands for TLR2 (LTA), TLR3 (PolyI:C), TLR4 (LPS), or TLR9 (CpG 2395, a type C oligonucleotide) stimulate human foreskin fibroblasts (HFF) by measuring IL- 8 secretion since IL- 8 is secreted by a wide variety of cell types in response to stimulation by TLR ligands [21]. HFF secreted IL-8 in response to stimulation with Poly I:C and LPS in a dose dependent fashion (Fig. 1A). In contrast, HFF did not secrete significant levels of IL-8 in response to stimulation with LTA or CpG 2395 (Fig. 1A). Since TLR ligands can induce the secretion of other cytokines in some types of cells, we also assayed HFF supernatants for IL-12 p40, IL10 , TNF- $\alpha$, and interferon- $\alpha$. None of these cytokines were detected after stimulation of HFF with LTA, CpG 2395, LPS, or Poly I:C (data not shown).

\section{TLR3 and TLR4 ligands inhibit HCMV infection in HFF}

After stimulation with TLR ligands, HFF were washed and infected with CMVPT30-gfp. After culture, the number of infected cells was determined by quantifying GFP-expressing cells (Fig. 1B). Treatment of HFF with LPS at doses as low as $0.1 \mu \mathrm{g} / \mathrm{ml}$ resulted in a $92 \%$ reduction in the number of GFP-positive cells (Fig. 1C). Treatment with $0.1 \mu \mathrm{g} / \mathrm{ml}$ Poly I:C resulted in a $63 \%$ reduction in the number of infected cells, while at doses of $1 \mu \mathrm{g} / \mathrm{ml}$ and 10 $\mu \mathrm{g} / \mathrm{ml}$ of Poly $\mathrm{I}: \mathrm{C},>97 \%$ reduction in the number of infected cells was observed (Fig. 1C). In contrast, pretreating HFF with LTA at doses as high as $100 \mu \mathrm{g} / \mathrm{ml}$ or 10 $\mu \mathrm{g} / \mathrm{ml}$ CpG did not significantly inhibit infection. Thus, pre-treatment of HFF with TLR3 and TLR4 ligands, but not TLR2 or TLR9 ligands, inhibited HCMV infection.

\section{Time dependence of TLR stimulation for HCMV inhibition and IL-8 production}

The effect of timing of TLR-ligand exposure on inhibition of HCMV infection production was next investigated using the concentration of each TLR-ligand that most effectively inhibited infection in the above experiments. When HFF were exposed to TLR ligands for 2 hours, $72 \%$ inhibition of GFP-positive cells was observed in response to Poly I:C, while only $9 \%$ inhibition was observed in response to LPS (Fig. 2A). However, both Poly I:C and LPS induced $>98 \%$ inhibition of HCMV infection when present for 24 hours in cell culture. Anti-HCMV responses induced by Poly I:C and LPS were similar whether cells were exposed to TLR ligands for 24 hours, 48 hours or 

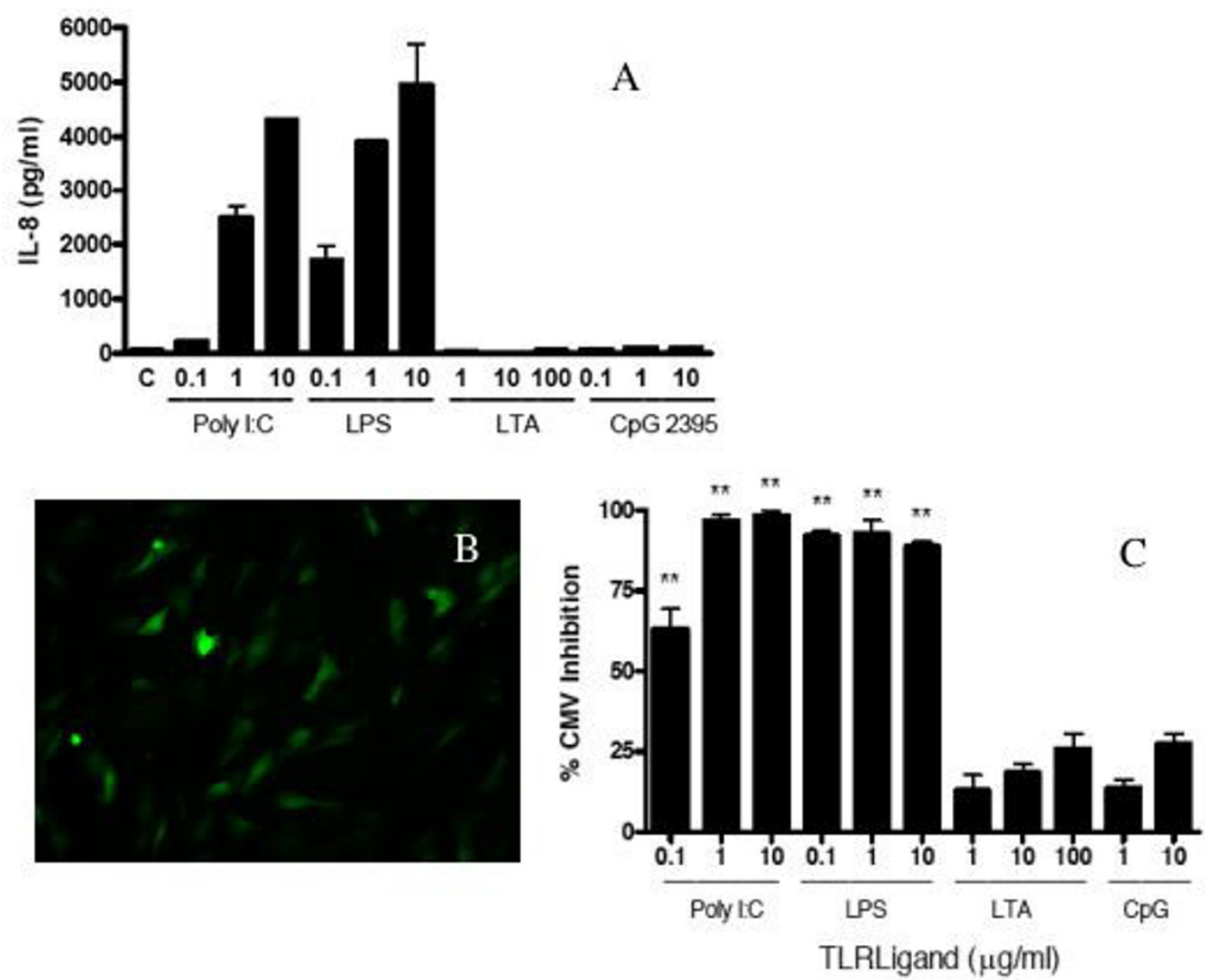

\section{Figure I}

IL-8 secretion and HCMV inhibition in HFF induced by TLR ligands. HFF cells were cultured to $95 \%$ confluency and stimulated with the indicated doses of TLR ligands or medium control alone (C) for 24 hours. A. Culture supernatants were then collected and assayed for IL-8 by ELISA. IL-8 secretion from one experiment representative of three. Bars represent mean \pm SD of triplicate cultures. B and C. After treatment of HFF with medium alone, LTA, Poly I:C, LPS, or CpG 2395 for 24 hours, cells were washed and CMVPT30-gfp was added. After four hours, the virus innoculum was removed and replaced with fresh culture medium. HCMV infection was quantified on day 10 post-infection by counting fluorescent (GFP expressing) cells in each well. B. Shown is a representative culture well from cells treated with medium alone. C. Percent inhibition compared to medium control. Results of one experiment, representative of 3 independent experiments, is shown. Bars represent mean \pm $\mathrm{SD}$ of triplicate cultures. * indicates $\mathrm{P} \leq 0.05$ compared to control. ** indicates $\mathrm{P} \leq 0.0 \mathrm{I}$ compared to control. *** indicates $\mathrm{P} \leq$ 0.00 I compared to control.

when stimulated for 24 hours and then incubated in the absence of stimulus for 24 hours before infection (Fig. 2A). When CpG was present for 2 hours, a significant $23 \%$ inhibition ( $\mathrm{p}<0.05)$ of HCMV replication was noted. However, CpG did not significantly inhibit HCMV when present for 24, 48 hours or 24 hours followed by resting for 24 hours. LTA did not inhibit HCMV at any of the times (not shown). These results show that 24 hours of exposure to Poly I:C and LPS resulted in a maximal antiHCMV effect.
The effect of time of cell stimulation with TLR ligands on IL-8 production was also determined. Stimulation of HFF cells with Poly I:C for 2 hours did not induce significant secretion of IL- 8 above control, although IL- 8 was detected after 2 hours exposure to LPS (Fig. 2B). The amount of IL- 8 detected after 24 hours of stimulation was higher than after 2 hours for both Poly I:C and LPS (Fig. $2 \mathrm{~B})$. The amount of IL-8 detected after stimulation with Poly I:C and LPS for 48 hours was similar to 24 hour stim- 

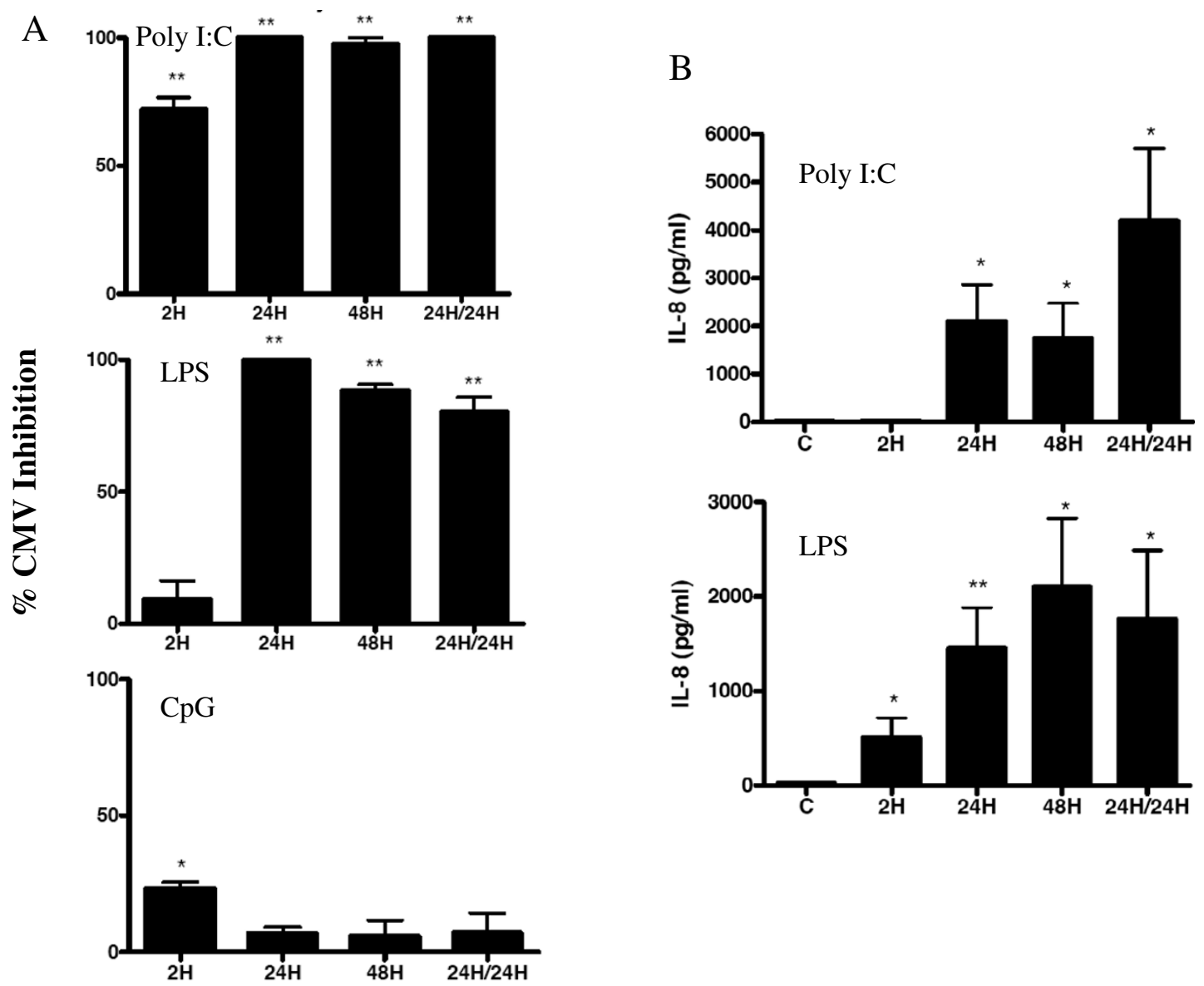

\section{Figure 2}

The effect of time of TLR stimulation on HCMV infection and IL-8 secretion in Foreskin Fibroblasts. A. Cell monlayers were treated with medium alone, Poly I:C, LPS or CpG 2395 (all at $10 \mu \mathrm{g} / \mathrm{ml}$ ) for either 2 hours, 24 hours, 48 hours, or for 24 hours followed by a period of 24 hours with fresh complete medium (24/24 group) and then challenged with CMVPT30-gfp. At day 10 post-infection the number of gfp-expressing foci were determined by fluorescence microscopy and the percent inhibition was calculated based on medium control-treated cells. B. Cells were stimulated with medium alone (control, C) or the indicated dose of the TLR ligands for a period of 2 hours, 24 hours, 48 hours, or for 24 hours followed by a period of 24 hours with fresh complete medium (24/24 group). Culture supernatants were immediately harvested and IL-8 levels determined by ELISA. For both $A$ and $B$ bars represent mean \pm SD of triplicate cultures. * indicates $\mathrm{P} \leq 0.05$ compared to control. ** indicates $\mathrm{P} \leq 0.00 \mathrm{I}$ compared to control.

ulation. There was no IL-8 produced by HFF in response to CpG or LTA (data not shown).

\section{Anti-HCMV effect of TLR3 and TLR4 ligands in HFF is mediated by IFN $\beta$}

Since fibroblasts are known to produce interferon-beta (IFN $\beta$ ) in response to stimulation with LPS and Poly I:C $[22,23]$, we hypothesized that the anti-HCMV effects resulting from stimulation of HFF with TLR ligands were mediated by IFN $\beta$. To determine if IFN $\beta$ was present, HFF were stimulated with LTA, Poly I:C, LPS, or CpG 2395 for 24 hours and the level of IFN $\beta$ was measured in culture supernatants by ELISA. Poly I:C at $10 \mu \mathrm{g} / \mathrm{ml}$ induced detectable IFN $\beta$, while LPS induced detectable levels of IFN- $\beta$ at $1 \mu \mathrm{g} / \mathrm{ml}$ and $10 \mu \mathrm{g} / \mathrm{ml}$ (Fig. 3). In contrast, LTA and $\mathrm{CpG}$ did not induce detectable IFN- $\beta$ (data not shown).

We next determined if IFN $\beta$ produced by HFF in response to Poly I:C or LPS was responsible for mediating antiHCMV effects. HFF were stimulated with Poly I:C or LPS for 24 hours, washed, and cultured an additional 24 hours to produce conditioned medium. Conditioned medium was treated with rabbit polyclonal anti-IFN $\beta$ antiserum or control antiserum and added to fresh HFF prior to HCMV infection. In the absence of IFN $\beta$ neutralizing antibody, 


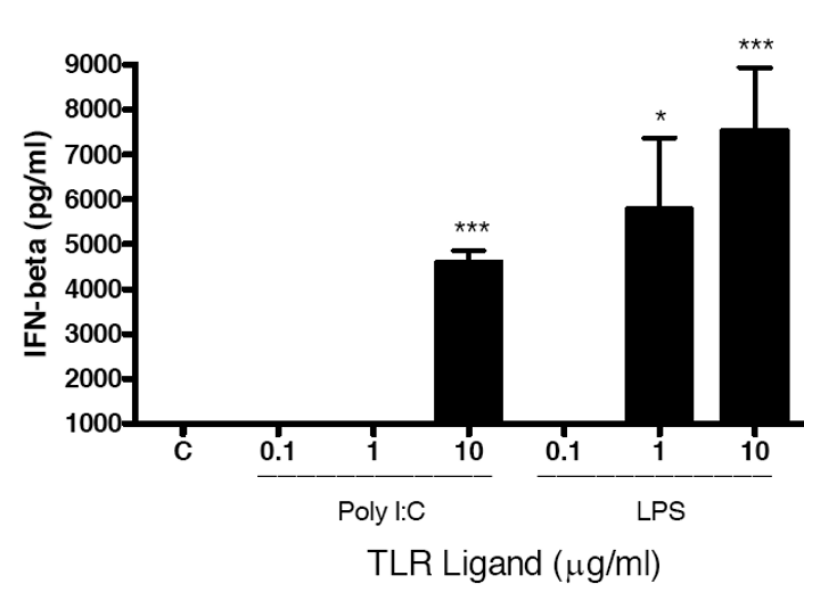

Figure 3

Poly I:C and LPS induce IFN $\beta$ secretion by Foreskin Fibroblasts. Monolayers of foreskin fibroblasts were stimulated with the indicated doses of TLR ligands or medium alone (Control, C) for 24 hours. Culture supernatants were collected and tested for IFN $\beta$ by ELISA. The limit of detection of this assay was $1000 \mathrm{pg} / \mathrm{ml}$. * indicates $\mathrm{P} \leq 0.05 \mathrm{com}$ pared to control. ** indicates $\mathrm{P} \leq 0.0 \mathrm{l}$ compared to control. $* * *$ indicates $\mathrm{P} \leq 0.00$ I compared to control.
Poly I:C-conditioned medium inhibited HCMV replication by $73 \%$ and LPS-conditioned medium inhibited HCMV replication by $84 \%$ (Fig 4). Addition of anti-IFN $\beta$ antibody reduced the ability of Poly I:C and LPS conditioned medium to inhibit HCMV, resulting in only $8 \%$ and $20 \%$ inhibition, respectively (Figure 4 ). In contrast, normal rabbit serum did not decrease the inhibition of HCMV infection of Poly I:C- and LPS-conditioned medium (Figure 4). These results show that stimulation with TLR3 and TLR4 ligands induced secretion of IFN $\beta$ that inhibited HCMV infection of HFF.

\section{TLR3, TLR4, and TLR9 ligands induce IL-8 secretion in ectocervical explant tissue}

The ability of TLR ligands to stimulate cells within ectocervical explant tissue was investigated by measuring IL-8 in culture supernatants. Poly I:C significantly induced IL-8 at 1 and $10 \mu \mathrm{g} / \mathrm{ml}(\mathrm{p}<0.001)$ (Fig 5A). LPS induced detectable IL-8 at all concentrations, although at lower levels than Poly I:C. In contrast to HFF, ectocervical explant tissues secreted IL- 8 in response to CpG at 1 and $10 \mu \mathrm{g} / \mathrm{ml}$. LTA did not induce IL-8.

\section{TLR2, TLR3, TLR4, and TLR9 ligands inhibit HCMV} infection in ectocervical explant tissue

The ability of TLR ligands to inhibit HCMV infection was next evaluated by real-time PCR for HCMV DNA instead

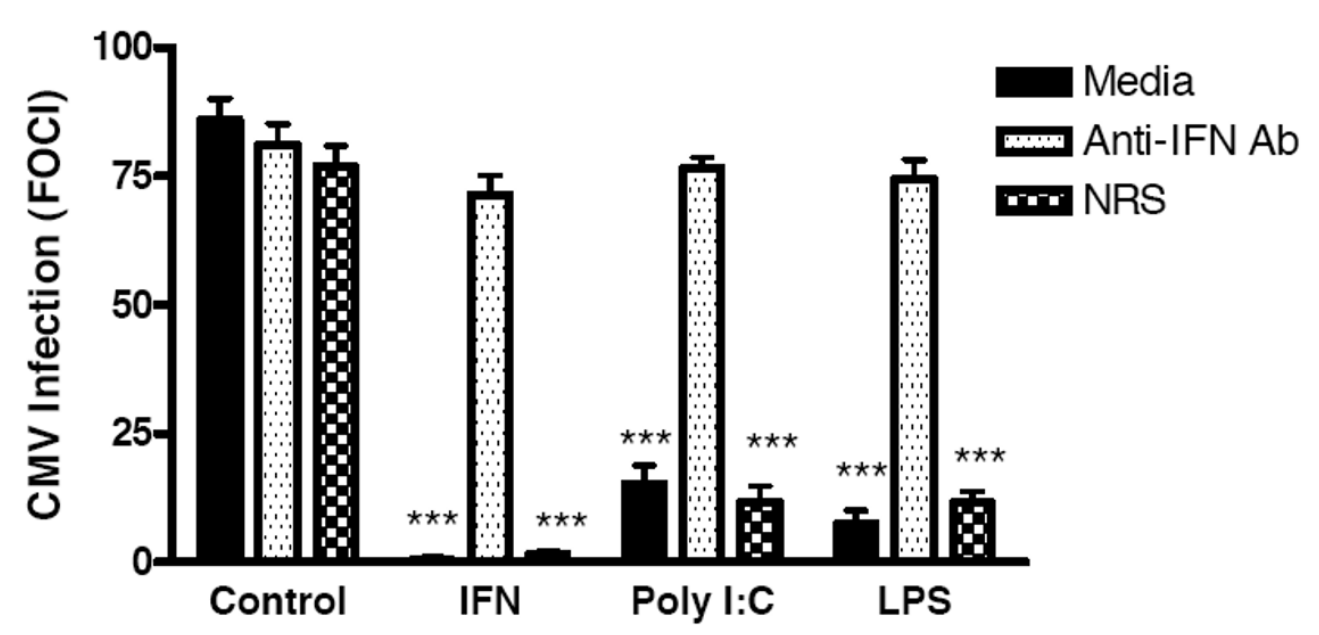

Figure 4

IFN $\beta$ induced by Poly I:C and LPS mediates resistance to HCMV in HFF. Monolayers of HFF were treated with either medium alone, Poly I:C $(10 \mu \mathrm{g} / \mathrm{ml})$ or LPS $(10 \mu \mathrm{g} / \mathrm{ml})$ for 24 hours. Cells were washed three times and cultured for an additional 24 period in one $\mathrm{ml}$ of fresh medium. These conditioned supernatants were collected and incubated in the presence of either medium as a control, rabbit polyclonal anti-IFN $\beta$ antibody, or normal rabbit serum for I hour at $37^{\circ} \mathrm{C}$. Recombinant IFN $\beta$ (IFN) was also incubated in the presence of either medium as a control, rabbit polyclonal anti-IFN $\beta$ antibody, or normal rabbit serum for I hour at $37^{\circ} \mathrm{C}$. The treated supernatants were then transferred to wells of confluent HFF fibroblasts and cultured for 24 hours. The conditioned medium was removed and the fresh HFF were challenged with CMVPT30-gfp. Fluorescent cells were then counted on day 10 post-infection (PI). The data shown is representative of 3 independent experiments. *** indicates $\mathrm{P} \leq 0.00$ I compared to control. 
of counting fluorescent cells since GFP-positive cells were observed, but difficult to accurately count in the threedimensional tissue matrix. Ectocervical explant tissue was incubated with Poly I:C, LPS, CpG, or LTA for 24 hours prior to infection and tissues were harvested 12 days after infection to determine HCMV DNA levels. Previous studies indicated that this time point was near the peak of HCMV levels [18]. Both Poly I:C and LPS significantly inhibited HCMV infection at $1 \mu \mathrm{g} / \mathrm{ml}$ and $10 \mu \mathrm{g} / \mathrm{ml}$ (Fig. 5B). However, LPS also inhibited HCMV infection at 0.1 $\mu \mathrm{g} / \mathrm{ml}$ (Fig 5). CpG inhibited HCMV infection significantly at $10 \mu \mathrm{g} / \mathrm{ml}(\mathrm{p}<0.0001)$. Surprisingly, LTA inhibited HCMV infection significantly at $100 \mu \mathrm{g} / \mathrm{ml}(\mathrm{p}<$ $0.001)$.
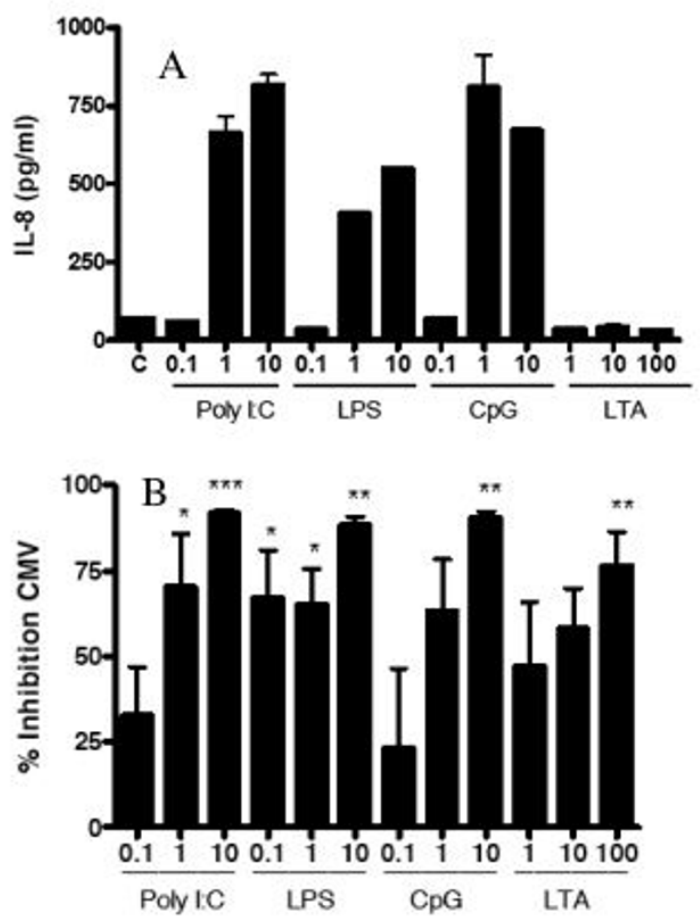

Figure 5

TLR Ligands induce IL-8 secretion and inhibit HCMV infection in Ectocervical explant tissue. A. Ectocervial explant tissue was incubated with TLR ligands for 24 hours. Supernatants were removed and assayed for IL-8 by ELISA. The mean \pm SD of triplicate cultures is shown from one experiment that is representative of three separate experiments. B. Ectocervical explant tissue was incubated with TLR ligands for 24 hours. Tissues were infected with HCMV and levels of HCMV were assessed by real time PCR after 12 days of culture. Average of three experiments. * indicates $\mathrm{P} \leq$ 0.05 compared to control. $* *$ indicates $\mathrm{P} \leq 0.0$ I compared to control while ${ }^{* * *}$ indicates $\mathrm{P} \leq 0.00 \mathrm{I}$.

\section{IFN- $\beta$ mediates anti-HCMV effect of TLR-ligands in ectocervical explant tissue}

We next determined whether IFN $\beta$ was involved in the anti-HCMV effect of the TLR ligands in ectocervical explant tissue. Conditioned medium was collected after 24 hours of stimulation of ectocervical explant tissue with Poly I:C, LPS, CpG, or LTA. Poly I:C conditioned medium inhibited HCMV infection by $61 \%$ and the inhibition was completely reversed by the presence of anti-IFN $\beta$ antibody but not control serum (Fig. 6). Although LPS did not induce IL- 8 as potently as Poly I:C in ectocervical tissues, LPS conditioned medium inhibited HCMV infection by $91 \%$, and the inhibition was reversed by neutralization of IFN $\beta$ (Fig. 6). CpG conditioned medium also significantly inhibited HCMV infection (71\%) and inhibition was shown to be dependent on the presence of IFN $\beta$ (Fig 6). Although LTA did not induce significant levels of IL-8 in ectocervical tissue, conditioned medium from LTA-treated ectocervical tissues inhibited HCMV infection by $56 \%$ and this was reversed by anti-IFN $\beta$. These results demonstrate that IFN $\beta$ contributes to the anti-HCMV effect of TLR2, TLR3, TLR4, and TLR9 ligands in ectocervical tissues. No interferon- $\alpha$ was detected in supernatants of TLR-stimulated cultures by ELISA (not shown).

\section{Expression of TLR by HFF and ectocervical tissue}

An anti-HCMV response was observed by ectocervical tissue in response to all TLR ligands but in HFF only in response to TLR3 and TLR4 ligands. These findings suggested that ectocervical tissue and HFF differentially expressed TLR. To determine expression of TLR, mRNA from HFF and ectocervical tissue was isolated, reverse transcribed, subjected to PCR and the products visualized on gels. The THP-1 cell line was similarly analyzed since these cells are know to express multiple TLR [24]. Bands were observed after amplification of ectocervical tissue cDNA and THP-1 cells cDNA for all four TLR (Fig. 7). In contrast, for HFF, bands were observed only for TLR3 and TLR4 suggesting a lack of expression of TLR2 and TLR9 by these cells.

\section{Discussion}

Sexually transmitted microbial diseases or bacterial vaginosis expose genital tract cells to TLR ligands. In this study we performed experiments to determine if exposure to defined TLR ligands affects HCMV infection and found that TLR ligands inhibit HCMV infection of both HFF and ectocervical explant tissue through induction of IFN $\beta$. While no previous studies directly investigated the effect of TLR ligand stimulation of cells in vitro on HCMV infection, Sainz et al [25] showed that the pretreatment of HFF with either IFN- $\alpha$, IFN $\beta$, or IFN- $\gamma$ inhibited HCMV infection. Several previous studies showed induction of IFN $\beta$ in HFF, HEK fibroblasts, and human lung fibroblasts in response to stimulation with Poly I:C [26-28]. 


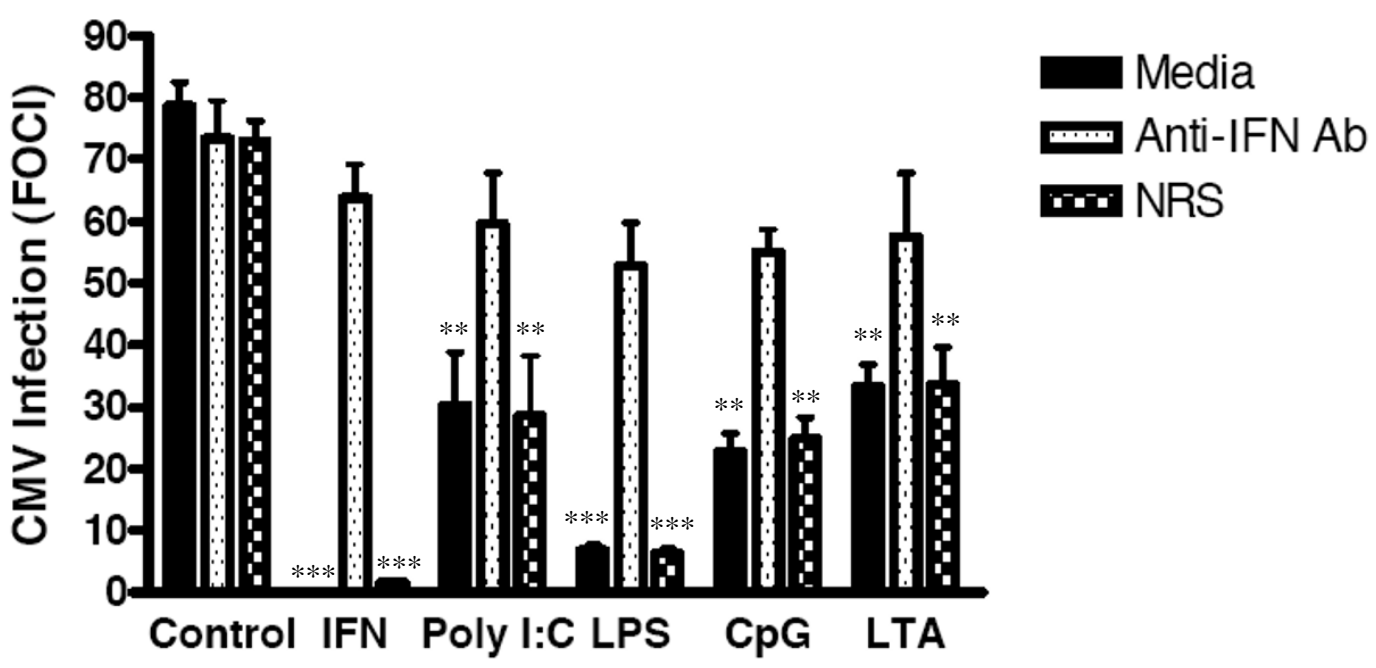

Figure 6

IFN $\beta$ induced in Ectocervical tissue by TLR ligands mediates resistance to HCMV. Ectocervical tissue was treated for 24 hours with TLR ligands. Tissues were washed three times and cultured for an additional 24 period in one ml of fresh medium. These conditioned supernatants were collected and incubated in the presence of either medium as a control, rabbit polyclonal anti-IFN $\beta$ antibody, or normal rabbit serum for I hour at $37^{\circ} \mathrm{C}$. The treated supernatants were then transferred to wells of confluent HFF and cultured for 24 hours. The conditioned medium was removed and treated HFF were challenged with CMVPT30-gfp. Foci of infection containing gfp-expressing cells were then counted on day 10 post-infection. The data shown is the mean \pm SD from one experiment that is representative of 3 independent experiments. $* *$ indicates $P \leq 0.01$ compared to control. **** indicates $\mathrm{P} \leq 0.00$ I compared to control.

While the effect of genital microbial infections on initial HCMV infection of women has not been reported, Ross et al. [4] recently reported that HCMV shedding was found

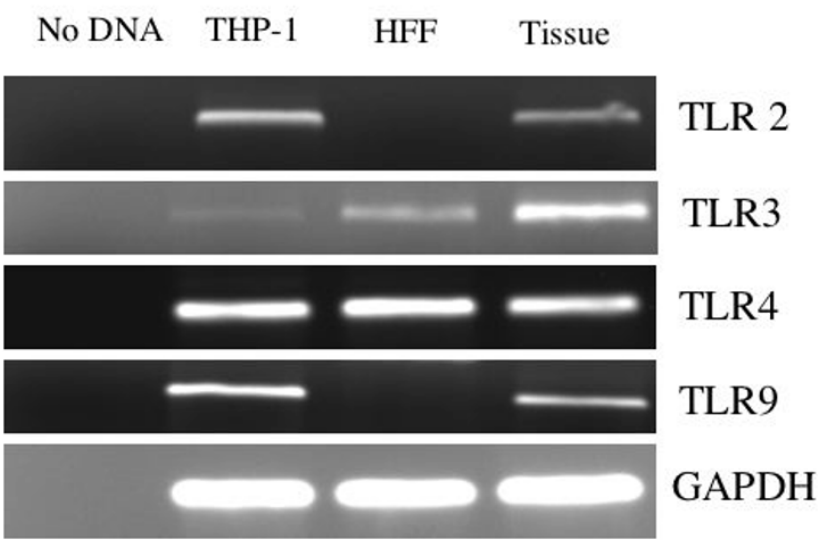

\section{Figure 7}

Expression of TLR by HFF and Ectocervical tissue. Expression of TLR2, TLR3, TLR4 and TLR9 in cells and tissue was assessed by reverse-transcription PCR. mRNA was isolated from THP-I monocytic cells, HFF and tissue and reverse transcribed to create cDNA which was subjected to PCR using primers for each of the TLR as well as for GAPDH. at a higher rate in women with $\mathrm{BV}$ than in women with normal flora. Infection with $T$. vaginalis, gonorrhea, and BV were independently associated with intrauterine transmission of HCMV [7]. Thus, these clinical studies show that under some in vivo conditions, HCMV infection can be enhanced by infections with other infectious agents. This suggests that TLR ligands may enhance HCMV infection in vivo since GC, T. vaginalis and BV all have TLR ligands (TLR2, TLR4 and TLR2 respectively) associated with their infections [8-10]. The clinical studies contrast with the findings of our in vitro and ex vivo studies where inhibition by defined TLR ligands was observed. A possible explanation for the differences could be that many of the clinical infections are chronic infections that in vitro 24 and 48 hour treatments with TLR ligands fail to accurately model. Also, in vivo adaptive immune responses or other stimuli may be present that affect HCMV that are lacking in vitro. Further studies are needed to understand these apparent differences.

A recent study showed that during infection with murine $\mathrm{CMV}$, virus replicates to higher levels in mice lacking TLR2 [29]. Depletion of Natural Killer (NK) cells eliminated the difference between TLR2-positive and TLR2-negative mice suggesting NK cells were involved in virus suppression in TLR2-positive mice. Also, type 1 interferon was lower in the TLR2 negative mice suggesting a role in virus suppression. The CMV inhibition in mice is different than the in 
vitro HCMV inhibition described in our study since in the mice no exogenous TLR ligands were given before infection. Intact HCMV virions have been reported to activate TLR2, possibly via glycoproteins $B$ and $H[30,31]$, although murine CMV is not known to have this activity. Iverson et al. [32] showed that human NK cells can suppress HCMV through secretion of IFN $\beta$, and NK cells can be stimulated through certain TLR including TLR2 [33]. In our in vitro studies, no NK cells were present in HFF cultures showing that TLR3- and TLR4-ligands had a direct effect on the HCMV infection targets. However, in ectocervical tissue, it is possible that targets of HCMV infection as well as non-targets, such as immune cells, could have produced interferons. In mice, murine HCMV replicates to higher levels in mice deficient in TLR9 or MyD88 [34,35]. This higher replication is again associated with lower levels of type 1 IFN and decreased NK cell activity. However, mouse embryonic fibroblasts, dendritic cells and macrophges, and human fibroblasts have all been shown to secrete IFN $\beta$ in response to stimulation with LPS [22,3638 . Thus, it is likely that multiple cell types in ectocervical tissues secrete IFN $\beta$ and contribute to the anti-HCMV effect.

Another interesting observation made in the current study was that the response pattern to the TLR ligands was different between HFF and ectocervical explants. Anti-HCMV responses in HFF were only found with TLR4 and TLR3 ligands while significant HCMV inhibition was induced by ligands to TLR2, TLR3, TLR4 and TLR9 in ectocervical explants. In our studies, IL-8 was measured to determine the responsiveness of HFF and explants to the TLR ligands. The IL-8 response pattern to the TLR ligands was also different between HFF and ectocervical explants with only TLR3 and TLR4 ligands inducing IL-8 in HFF but TLR3, TLR4 and TLR9 ligands inducing IL-8 in the tissue. Analysis of mRNA indicated that the ectocervical tissue expressed all four of the TLR while HFF only expressed TLR3 and TLR4. Many cell types express restricted repertoires of TLR receptors. For example, many epithelial cells have been observed to lack expression of TLR4 but to respond to TLR2 ligands [39]. This highlights the importance of using models to study HCMV infection that most closely mirror the types of cells that are present in vivo. Cultures of ectocervical tissue have been used to study factors that affect HIV-infection [20] and to assess the interactions of HIV with HCMV [18], but this is the first study to investigate how TLR ligands affect HCMV infection in this tissue.

The inability of a TLR9 ligand to inhibit HCMV in HFF may be due to a lack of expression of TLR9 in these cells. TLR2 is not generally recognized to activate signaling pathways that lead to IFN production and may explain the lack of anti-HCMV effect in HFF due to this TLR ligand
[40]. However, TLR2 induced an anti-HCMV effect in ectocervical tissue and this appeared to be dependent on IFN $\beta$. The mechanism for induction of IFN $\beta$ by TLR 2 in tissues is not known although as mentioned above, some cells may produce IFN in response to TLR2 ligands. Also, stimulation through TLR2 can upregulate a number of molecules involved in anti-viral responses such as TRIF [41] possibly leading to enhanced IFN production by cells due to other stimuli.

In conclusion this study shows that defined TLR ligands inhibit HCMV replication via IFN $\beta$ which suggests that different types of flora in the female genital tract can influence HCMV infection. This further suggests that reactivation and shedding of HCMV in the genital tract may be determined by alterations in the normal flora, which results from underlying conditions such as bacterial vaginosis or sexually transmitted diseases.

\section{Authors' contributions}

SH performed all of the cultures experiments and participated in writing of the manuscript. NL obtained and processed cervical tissue and provided direction to the studies. MRZ performed the TLR expression studies. GTS provided overall direction and co-wrote the manuscript. All authors read and approved the final manuscript.

\section{Acknowledgements}

The authors acknowledge Carl Ware for helpful discussion of the work. This work was supported by NIH grants AI065308 and Al48073.

\section{References}

I. Staras SA, Dollard SC, Radford KW, Flanders WD, Pass RF, Cannon MI: Seroprevalence of cytomegalovirus infection in the United States, I 988- I 994. Clin Infect Dis 2006, 43(9): I |43-I I5 I.

2. Fishman JA, Rubin $\mathrm{RH}$ : Infection in organ-transplant recipients. N Engl J Med I998, 338(24):|74|-I75I.

3. Handsfield HH, Chandler SH, Caine VA, Meyers JD, Corey L, Medeiros E, McDougall JK: Cytomegalovirus infection in sex partners: evidence for sexual transmission. J Infect Dis 1985, I 5 I (2):344-348.

4. Ross SA, Novak Z, Ashrith G, Rivera LB, Britt WJ, Hedges S, Schwebke JR, Boppana AS: Association between genital tract cytomegalovirus infection and bacterial vaginosis. J Infect Dis 2005, 192(10): 1727-1730.

5. Sobel JD: Vaginitis. N Engl J Med 1997, 337(26): |896-1903.

6. Clarke LM, Duerr A, Feldman J, Sierra MF, Daidone BJ, Landesman $\mathrm{SH}$ : Factors associated with cytomegalovirus infection among human immunodeficiency virus type I-seronegative and -seropositive women from an urban minority community. J Infect Dis 1996, I 73(1):77-82.

7. Fowler KB, Pass RF: Sexually transmitted diseases in mothers of neonates with congenital cytomegalovirus infection. J Infect Dis 1991, I 64(2):259-264.

8. Fisette PL, Ram S, Andersen JM, Guo W, Ingalls RR: The Lip lipoprotein from Neisseria gonorrhoeae stimulates cytokine release and NF-kappaB activation in epithelial cells in a Tolllike receptor 2-dependent manner. The Journal of biological chemistry 2003, 278(47):46252-46260.

9. Zariffard MR, Harwani S, Novak RM, Graham PJ, Ji X, Spear GT: Trichomonas vaginalis infection activates cells through toll-like receptor 4. Clin Immunol 2004, I I I(I): I03-I07.

10. Mares D, Simoes JA, Novak RM, Spear GT: TLR2-mediated cell stimulation in bacterial vaginosis. J Reprod Immunol 2007. 
II. Ishii KJ, Akira S: Innate immune recognition of nucleic acids: beyond toll-like receptors. Int J Cancer 2005, II 7(4):5I7-523.

12. Ashkar AA, Bauer S, Mitchell WJ, Vieira J, Rosenthal KL: Local delivery of CpG oligodeoxynucleotides induces rapid changes in the genital mucosa and inhibits replication, but not entry, of herpes simplex virus type 2 . J Virol 2003, 77(16):8948-8956.

13. Sato $A$, Iwasaki $A$ : Induction of antiviral immunity requires Toll-like receptor signaling in both stromal and dendritic cell compartments. Proc Natl Acad Sci U S A 2004 I0I(46): I 6274- 16279 .

14. Isogawa M, Robek MD, Furuichi Y, Chisari FV: Toll-like receptor signaling inhibits hepatitis B virus replication in vivo. J Virol 2005, 79(I I):7269-7272

15. Gill N, Deacon PM, Lichty B, Mossman KL, Ashkar AA: Induction of innate immunity against herpes simplex virus type 2 infection via local delivery of Toll-like receptor ligands correlates with beta interferon production. J Virol 2006, 80(20):9943-9950.

16. Isomura $\mathrm{H}$, Stinski MF: The human cytomegalovirus major immediate-early enhancer determines the efficiency of immediate-early gene transcription and viral replication in permissive cells at low multiplicity of infection. J Virol 2003 77(6):3602-36|4.

17. Caliendo AM, Yen-Lieberman B, Baptista J, Andersen J, Crumpacker C, Schuurman R, Spector SA, Bremer J, Lurain NS: Comparison of molecular tests for detection and quantification of cell-associated cytomegalovirus DNA. Journal of clinical microbiology 2003, 4 I (8):3509-35। 3 .

18. Fox-Canale AM, Hope TJ, Martinson J, Lurain JR, Rademaker AW, Bremer JW, Landay A, Spear GT, Lurain NS: Human cytomegalovirus and human immunodeficiency virus type-I co-infection in human cervical tissue. Virology 2007.

19. Lurain NS, Kapell KS, Huang DD, Short JA, Paintsil J, Winkfield E, Benedict CA, Ware CF, Bremer JW: Human cytomegalovirus UL 44 open reading frame: sequence hypervariability in low-passage clinical isolates. J Virol 1999, 73( I 2): 10040-10050.

20. Hu Q, Frank I, Williams V, Santos JJ, Watts P, Griffin GE, Moore JP, Pope M, Shattock RJ: Blockade of attachment and fusion receptors inhibits HIV-I infection of human cervical tissue. J Exp Med 2004, 199(8): 1065-1075.

21. Harada A, Sekido N, Akahoshi T, Wada T, Mukaida N, Matsushima K: Essential involvement of interleukin-8 (IL-8) in acute inflammation. J Leukoc Biol 1994, 56(5):559-564.

22. Helfgott DC, May LT, Sthoeger Z, Tamm I, Sehgal PB: Bacterial lipopolysaccharide (endotoxin) enhances expression and secretion of beta 2 interferon by human fibroblasts. J Exp Med 1987, I66(5): 1300-1309.

23. Van Damme J, Schaafsma MR, Fibbe WE, Falkenburg JH, Opdenakker G, Billiau A: Simultaneous production of interleukin 6, interferon-beta and colony-stimulating activity by fibroblasts after viral and bacterial infection. European journal of immunology 1989, I (1):163-168.

24. Zariffard MR, Novak RM, Lurain N, Sha BE, Graham P, Spear GT: Induction of tumor necrosis factor- alpha secretion and tolllike receptor 2 and 4 mRNA expression by genital mucosal fluids from women with bacterial vaginosis. J Infect Dis 2005 , I91(II):1913-1921.

25. Sainz B Jr., LaMarca HL, Garry RF, Morris CA: Synergistic inhibition of human cytomegalovirus replication by interferonalpha/beta and interferon-gamma. Virol J 2005, 2: 14.

26. Vilcek J, Kohase M, Henriksen-DeStefano D: Mitogenic effect of double-stranded RNA in human fibroblasts: role of autogenous interferon. J Cell Physiol 1987, I30(I):37-43.

27. Servant MJ, Grandvaux N, tenOever BR, Duguay D, Lin R, Hiscott J: Identification of the minimal phosphoacceptor site required for in vivo activation of interferon regulatory factor 3 in response to virus and double-stranded RNA. The Journal of biological chemistry 2003, 278(I I):944I-9447.

28. Matsumoto M, Kikkawa S, Kohase M, Miyake K, Seya T: Establishment of a monoclonal antibody against human Toll-like receptor 3 that blocks double-stranded RNA-mediated signaling. Biochem Biophys Res Commun 2002, 293(5): 1364-1369.

29. Szomolanyi-Tsuda E, Liang X, Welsh RM, Kurt-Jones EA, Finberg RW: Role for TLR2 in NK cell-mediated control of murine cytomegalovirus in vivo. J Virol 2006, 80(9):4286-429I.

30. Compton T, Kurt-Jones EA, Boehme KW, Belko J, Latz E, Golenbock DT, Finberg RW: Human cytomegalovirus activates inflamma- tory cytokine responses via CDI 4 and Toll-like receptor 2. Virol 2003, 77(8):4588-4596.

3I. Boehme KW, Guerrero M, Compton T: Human cytomegalovirus envelope glycoproteins $B$ and $H$ are necessary for TLR2 activation in permissive cells. J Immunol 2006, I77( I 0):7094-7I 02.

32. Iversen AC, Norris PS, Ware CF, Benedict CA: Human NK cells inhibit cytomegalovirus replication through a noncytolytic mechanism involving lymphotoxin-dependent induction of IFN-beta. J Immunol 2005, I 75(I I):7568-7574.

33. Lauzon NM, Mian F, Mackenzie R, Ashkar AA: The direct effects of Toll-like receptor ligands on human NK cell cytokine production and cytotoxicity. Cell Immunol 2006.

34. Krug A, French AR, Barchet W, Fischer JA, Dzionek A, Pingel JT, Orihuela MM, Akira S, Yokoyama WM, Colonna M: TLR9-dependent recognition of MCMV by IPC and DC generates coordinated cytokine responses that activate antiviral NK cell function. Immunity 2004, 2 I(I): 107-I I9.

35. Tabeta K, Georgel P, Janssen E, Du X, Hoebe K, Crozat K, Mudd S, Shamel L, Sovath S, Goode J, Alexopoulou L, Flavell RA, Beutler B: Toll-like receptors 9 and 3 as essential components of innate immune defense against mouse cytomegalovirus infection. Proc Natl Acad Sci U S A 2004, 101 ( I 0):351 6-352I.

36. Doyle S, Vaidya S, O'Connell R, Dadgostar H, Dempsey P, Wu T, Rao G, Sun R, Haberland M, Modlin R, Cheng G: IRF3 mediates a TLR3/TLR4-specific antiviral gene program. Immunity 2002, I 7(3):25I-263.

37. Toshchakov V, Jones BW, Perera PY, Thomas K, Cody MJ, Zhang S, Williams BR, Major J, Hamilton TA, Fenton MJ, Vogel SN: TLR4, but not TLR2, mediates IFN-beta-induced STATIalpha/betadependent gene expression in macrophages. Nat Immunol 2002, 3(4):392-398.

38. Youn HS, Lee JY, Fitzgerald KA, Young HA, Akira S, Hwang DH: Specific inhibition of MyD88-independent signaling pathways of TLR3 and TLR4 by resveratrol: molecular targets are TBKI and RIPI in TRIF complex. J Immunol 2005, I75(5):3339-3346.

39. Fichorova RN, Cronin AO, Lien E, Anderson DJ, Ingalls RR: Response to Neisseria gonorrhoeae by cervicovaginal epithelial cells occurs in the absence of toll-like receptor 4mediated signaling. J Immunol 2002, I68(5):2424-2432.

40. van Duin $D$, Medzhitov $R$, Shaw AC: Triggering TLR signaling in vaccination. Trends Immunol 2006, 27(I):49-55.

4I. Hardy MP, Mc GGAF, O'Neill LA: Transcriptional regulation of the human TRIF (TIR domain-containing adaptor protein inducing interferon beta) gene. Biochem J 2004, 380(Pt I):83-93.

Publish with Biomed Central and every scientist can read your work free of charge

"BioMed Central will be the most significant development for disseminating the results of biomedical research in our lifetime. "

Sir Paul Nurse, Cancer Research UK

Your research papers will be:

- available free of charge to the entire biomedical community

- peer reviewed and published immediately upon acceptance

- cited in PubMed and archived on PubMed Central

- yours - you keep the copyright
BioMedcentral 